\title{
Literary Adaptation and Market Value: Encounters with the Public in the Early Career of Roger McDonald
}

\author{
Christopher Lee \\ chris.lee@griffith.edu.au
}

In The world republic of letters, Pascale Casanova suggests that an intimate relation between politics and literature is a feature of postcolonial nations because the relative lack of literary capital on the margins prevents the autonomy that is available to writers in the great national literary spaces such as France, England and the United States. ${ }^{1}$ The pressing imperatives of post-colonial responsibility certainly pose a particular challenge for contemporary Australian novelists aspiring not just to local distinction, but also access to international markets and a wider reputation in the world republic of letters. In Australia, the writer's aspiration to a wider market share and greater cultural capital has often been construed as a forlorn search for a reliable readership. An established following provides a foundation for the development of a consistent artistic oeuvre, which is in turn able to support the critical topoi of canonisation: promise, originality, development and genius.

In her contribution to Overland's 'Criticism and Fiction' debate in 2008 Susan Lever made a point about the unreliable readership for the contemporary Australian novel, and speculated on its effects: 'American writers know that there are people out there, paying money and devoting substantial amounts of precious time to reading their books. Australian writers can't be so certain'. ${ }^{2}$ This is why state subsidisation of the culture industries has been a persistent, if still controversial, feature of our literary history over the last fifty years. And it is the reason, Lever suggests, why many Australian novels defy — even antagonise — their audience. Dorothy Green made a similar point about the unreliability of the Australian reading public in an opinion piece in the National Times over thirty years ago: 'What an Australian writer needs most,' she argued, 'is a book-buying audience which he [sic] can take for granted'. ${ }^{3}$

A clipping of Green's essay lies preserved in the National Library of Australia in Canberra in the personal papers relating to Roger McDonald's first novel, 1915. As an artefact, it offers a useful point of entry for an examination of the search for a reading public in McDonald's early career. McDonald, who was born in 1941, is now a writer of literary significance. He is the author of nine novels, two novelisations of film scripts (1988 and 1992), two television scripts, one (non) fictionalised memoir and two volumes of poetry. ${ }^{4}$ His achievement includes a significant record in the Australian list of literary awards and some signs that he is getting close to breaking into the major international prizes that distinguish the careers of Peter Carey, David Malouf and, more recently, Kate Grenville. 
McDonald's debut novel, 1915, gave his early career impetus. It won the Government Biennial Literature Prize in South Australia and was the Age Book of the Year in 1979. Something of a phenomenon, it was rewritten as a mini-series for ABC television and is the only one of his first five novels (1979-92) that is still in print. The award success of 1915 was followed by a rather long hiatus prior to the short-listing of Shearer's motel for the Miles Franklin award in 1993. That title was quickly withdrawn as ineligible, but it went on to win the NBC Banjo Award for Non-Fiction.

McDonald's sixth novel, Mr Darwin's shooter (1998), was therefore something of a breakthrough for him some twenty years after the success of 1915. It was simultaneously published by the Random House imprints Knopf in Sydney and Anchor in London, as well as Atlantic Monthly Press in New York, the hardcover imprint of the independent publisher Grove Atlantic. The novel was quickly translated into Spanish (2001) and German (2002), after it won the Christina Stead and Vance Palmer Prizes for Fiction at the New South Wales and Victorian Premiers' Awards in 1999 and the National Fiction and Premier's Literary Awards at the South Australian Festival Awards for Literature in 2000.

This shift in career momentum was confirmed by The ballad of Desmond Kale, which won the Miles Franklin Award in 2006 and began to register McDonald's name in association with international literary awards such as the Commonwealth Writers Prize, where it was short-listed for best book in the South East Asia and South Pacific Region, and the IMPAC Dublin Literary Award, where it was long listed in 2007. When the colts ran (2010), his penultimate novel to date, incorporates a long story that won the O. Henry prize in the United States in 2008; it was shortlisted for both the Indie and Miles Franklin awards in Australia.

In the late 1970s, the cross-media deals and literary awards that can help to establish some measure of financial security for a writer were all ahead of McDonald. In writing his first novel, he was aspiring to a literary reputation (among other things) and, like other novelists of his generation, he was eager for international publication and distribution. His position as a poetry editor at the University of Queensland Press (UQP) helped, because it placed him at the centre of an emerging literary network within a rapidly expanding and diversifying literary field.

Ken Gelder and Paul Salzman explain the flourishing of the Australian novel between 1970 and 1988 in terms of the expanding contexts for the creation, publication and reception of Australian work in the lead up to the Bicentennial. ${ }^{5}$ Government subsidy, the development of Australian lists by large presses, the emergence of smaller ones, the increasing prominence and proliferation of literary awards and writers festivals, and the investment of film and television production in local literary product all combined to increase the 'freedom' available to Australian writers. Australian writers were also reaching out across the globe in search of international opportunities.

Under the entrepreneurial guidance of the American Frank Thompson, UQP established a significant list of Australian writers, but it was confined to the shorter forms: poetry and short fiction. The Paperback Poets series, as it came to be known, helped to develop the reputations of a new generation of Australian poets such as Malouf, Michael Dransfield, Rodney Hall, Rhyll McMaster, Tom Shapcott, J. S. Harry, Robert Gray, Geoff Page, Jennifer Maiden, Judith Rodrigeuz, Andrew Taylor and Vicki Viidikas. McDonald edited the First paperback poets anthology 
in 1974 and added his own second personal collection, Airship, in the second Paperback Poets series the following year. At the same time, UQP began to develop a significant short fiction list with collections from Peter Carey (1974, 1979), Murray Bail (1975), Michael Wilding (1975), David Campbell (1976) and Nicholas Jose (1980).

Towards the end of the 1970s, UQP sought to extend its list into the more prestigious realm of the novel. 1915 was one of only six Australian novels published by UQP in seven years, and poets who published in McDonald's Paperback Poets series were responsible for four of them. ${ }^{6}$ Clearly one way to develop a list was to provide your established writers with an opportunity to pursue the longer form, and McDonald's position at UQP helped him to secure an advance contract from the press for his first novel and, on the back of that contract, an Australian Literature Board grant to support him while he finished the manuscript. UQP also received a grant to defray some of its production costs.

Government funding, of course, is an intervention in cultural production that registers Lever's and Green's concerns about the available readership. It also makes possible the antagonistic relation with the market that Lever sees as one of the signature features of predominately masculine forms of the Australian novel ${ }^{7}-$ although it needs to be said that this is not a charge that one might make about McDonald's oeuvre as a whole. Nevertheless, there is a clear critical turn in the two early novels that draws attention to the limitations of postcolonial mythology for understanding character, society or history. 1915 interrogates the Anzac legend critically, if respectfully; Slipstream subverts the imperial legends of pioneer aviation, which it models on the life and celebrity of Sir Charles Kingsford Smith. ${ }^{8}$

The plot of 1915 sets two love triangles against the background of Australia's early involvement in World War I. Both the military history and the romantic interests address a broad audience, but the storylines of both frustrate the expectations of personal and national fulfilment enshrined in popular convention. Walter Gilchrist is a member of a respectable farming family who is studying at university when war breaks out; his friend, Billy Mackenzie, labours under the disadvantages of his family's class and creed, and the two boys are cast productively as both friend and foe. Walter is betrayed and forgotten at home by the beautiful and precocious Frances Reilly before being ignominiously captured by the Turks abroad. Billy McKenzie loses Frances to Walter because of his class and education in the first instance, and then loses his fiancée Diane and their unborn child, who drown in a flooded river. He returns from the Dardenelles maddened as much by the injustices of this traumatic domestic turn of events as by the wounds of war.

The novel also frustrates a wider audience with its formal ambition. Chapters proceed episodically in chronological sequence, comprising short scenes that allow quick transitions in space and time and a mobile narrative perspective. The theme develops through the recurring juxtaposition of scenes that associate the experiences of characters separated in time and space, and the intricate design that results reveals the author's sociological and metaphysical interests. ${ }^{9}$ In short, there is a tension between the populist appeal of the subject-matter, the anxious turns of plot and characterisation, and the formal sophistication of the novel's modernist aesthetic.

1915 was launched in the Australian national capital, Canberra, on the eve of the remembrance services of Anzac Day in 1979 with a publicity campaign that most certainly would be the envy of any contemporary Australian author. A full-page 
advertisement in Bookseller and Publisher foreshadowed 'A brilliant new novel about Australia's coming of age' and an endorsement from the internationally distinguished poet, Les A. Murray, for 'One of the very best first novels I've ever read'. ${ }^{10}$ Three-inch box advertisements in the Age, Sydney Morning Herald, Australian, Courier-Mail, Canberra Times and National Times presaged the coming of the novel, and these were followed a month later by a round of 'now available' notices that pretty well guaranteed widespread review and attention. Press conferences, an author tour and launches in four capitals were supported with posters, bookmarks and stickers featuring a recognisable logo of the cover that memorably used a figure of a digger superimposed over the third digit of the numerical title. The same logo would feature on the later cover of the paperback and the publicity for the ABC television mini-series that followed in 1982. The launch in Canberra even featured polo players dressed as Light Horsemen who conducted riding displays on the lawns fronting Parliament House. ${ }^{11}$ It was a determined bid on behalf of a precocious début novel for the attention of a broader Australian audience.

The literary editor of Brisbane's Courier-Mail, David Rowbotham - himself a poet of merit - accepted the novel as 'a simple and deadly tale of War', ${ }^{12}$ and there was some truth in this. McDonald went to some lengths to research his representation of the Gallipoli scenes because he did not want to attract criticism for any misrepresentation of Australian soldiers. ${ }^{13}$ For a number of reviewers, though, the military subject, the romance plot and the modernist form seemed strange bedfellows. The Australian Defence Force Academy (ADFA)-based literary scholar Barry Andrews pointed out the ways in which the marketing move to connect the novel with Australian military mythology misconstrued it primarily as an historical novel about the Gallipoli campaign. ${ }^{14}$ The unnamed reviewer from the Gallipoli Gazette, who commented on the book from the standpoint of his military service rather than any identified literary expertise, also expressed some confusion:

This book goes into great detail of events at Gallipoli supplied by research and the personal experiences of returned soldiers, which may well have occurred. Still, I found it hard to follow. Unrelated and disjointed incidents abound. Witness: a group of convivial Australians strolling along the beach. Strolling? Convivial? Well. Well. A New Zealand officer sitting with his back to the beach, furiously puffing his pipe. Just that and then no more about him. Maybe all this was true. I do not know. I was not in the Light Horse. They may have been convivial. The poor bloody infantry (PBI) had very little to be amused about.

There is a lot more. Unrequited love. Unanswered letters from indifferent girls. Tragic happenings both at the front and at home. This, of course, does not mean the book is without interest. It is, I think, for those who would like to know the conditions those men had to suffer throughout that hideous campaign. ${ }^{15}$

The Gallipoli Gazette refers to the military rather than the romantic campaign when it discovers some merit in the novel - but this was, as Andrews pointed out, the wrong end of the stick. The novelist himself soon clarified 1915 as not 'a war book in the accepted sense', but a novel 'about the secret battles between men and women'. ${ }^{16}$ Les Murray showed himself to be rather idiosyncratically in on this view when he chose it as his favourite novel of the year. The poet placed it on a par with Stephen Crane's Red badge of courage before claiming that it was 
more than a book about the La Belle Dame Sans Merci, about deep warfare between men and women when they were expected to act almost as members of a different species, about rites of passage. For people of my generation it is probably a book about going to university. ${ }^{17}$

The desire to shift the emphasis of the novel from its depiction of war to its exploration of personal relationships suggests the need for caution with respect to the sacred standing of Anzac in Australian culture and society. During the production of the $\mathrm{ABC}$ television mini-series a few years later, McDonald attempted to distance the novel from the political debates associated with the public's growing public fascination with Australian military mythology:

It was just individuals caught up in something they did not understand ... it was an Australian moment and an Australian tragedy. I would not claim anything grandiose about it. I do not have any big grandiose nationalistic sentiments about it. We have come into a generation now where the story can be looked at for its own sake, not as something the left-wing believes we should debunk and the right-wing believes we should uphold. ${ }^{18}$

Looking at the human themes of the novel for their own sake rather than for their articulation with a monumental national history seeks to remove the literature from a field of attention that is politically over-determined. The qualification was necessary because the publicity campaign sought to stitch the literary audience together with a wider market by pitching it as a national romantic saga. By promoting the novel as a story 'about Australia's coming of age', the marketing campaign specifically sought to associate the romantic interests of the young lovers with the romantic aspirations of military mythology. This tactic borrowed from the marketing conventions that were established around the same time by the government-subsidised New Australian Cinema, and it is an illuminating comparison for understanding the novel's ultimately successful search for a wider public.

Tom O'Regan points out how a number of these government-subsidised films used 'a personal history set against the background of historical events' to establish their characters' transition from birth through to maturity as exemplars of 'the emergence of Australian culture and nationalism'. He argues that, 'The films were often marked by a concern with representative characters who are marked by their ordinariness and who are confined to their immediate social environment which they negotiate, are affected by, but themselves rarely affect. ${ }^{19}$ It is a familiar form of 'national fiction' persuasively identified by Graeme Turner in his influential study of the same name, and at the time it had specific purchase in the debate over the effectiveness of government funding of the arts. ${ }^{20}$ O'Regan goes on to make an interesting point about the ways in which these films were able to address different audiences:

On the one hand they were marked by their concern for alienation and moral sensibility (Harris, 1980), on the other hand, they furthered the national stereotypes of the battler, the little man or woman who struggles through over-riding social and historical situations and events but maintains his/her integrity in the process (Ryan 1980: 125-6). Their capacity to attract both readings was a function of their ability to bridge a minority and a majority public. ${ }^{21}$ 
UQP's marketing clearly covets the wider audience available to a commodity that can connect a minority cultural product with the sustaining mythologies of a majority public. Perhaps it coveted both the audiences brought into being by the New Australian Cinema as well as the funds that might come through the sale of film rights. Peter Weir's Gallipoli, which was in production at the time, was certainly a significant factor in planning the publication and promotion of the novel. Weir, through Geoffrey Dutton, was actually given access to a manuscript, and the paperback publication hoped to get a kick from the film's stimulation of the market. There are clear resonances between Weir's film and McDonald's novel that go beyond the simple matter of a shared subject. The American publisher George Brazillier readvertised the novel in New York when Weir's film was screening. ${ }^{22}$ Nevertheless, when cross-media rights were sold, they went to the Australian Broadcasting Commission $(\mathrm{ABC})$ for treatment on the small screen in the format of the mini-series.

The ABC's advance for the TV series assisted McDonald's move to Canberra to take up writing full time. It also underscored the importance of film and television rights to a sustainable career in writing, and it significantly influenced McDonald's writing career for decades. The textual pliability required to bridge a minority and majority public ${ }^{23}$ is arguably a more difficult task for the novel than a miniseries or film. This is particularly so with 1915 , because it is a formally ambitious work of modernist art. The novel is narrated by an intrusive third-person narrator, whose predominately bare prose is interrupted periodically by lyric moments and bursts of allusive style. These shifts in register provide tentative 'moments' of metaphysical transcendence, and were singled out for criticism by some reviewers. The complicated relationship between story and plot that unsettled the reviewer from the Gallipoli Gazette is characterised by short scenes that allow quick transitions in character, space and time, which establish the relationships between the four characters. The complex patterning of the novel also drew some criticism from the reviewers, and a number of them characterised it as a difficult read, which sometimes strays into pretentiousness in its attempts to conjure poetic and metaphysical registers. ${ }^{24}$

These styles, and the themes associated with them, were discarded from the miniseries by Peter Yeldham along with the modernist formal patterning of the book. ${ }^{25}$ McDonald's narrative was reconceived along the lines of the new Australian cinema and the translation of those cinematic codes on to the smaller screen. Yeldham also softened the novel's ending by adding a recuperative scene depicting a wiser and happier Walter in a prisoner-of-war camp at the end of the mini-series. Though to be fair to both Yeldum and the government-owned broadcaster that commissioned him, the series did retain some reflection on the mythologisation of Anzac. Working for the $\mathrm{ABC}$ may have made it a little easier for him to gently rock the boat than it may have been for those working in mainstream popular cinema or commercial television.

The adaptation of the novel for the small screen helped the paperback edition of the novel published by Fontana in 1980 to sell more than 77,000 copies. ${ }^{26}$ But it also overshadowed the follow-up novel, Slipstream, which was published in 1982. At the time, 1915, Slipstream and the potential of both for adaptation as film or television were considered important assets in UQP's efforts to secure international publication for its writers. ${ }^{27}$ The press wanted international options, so it could 
maintain its list and maximise the returns on its investment, but it quickly found itself in a stiff competition with the writers and their agents as well as rival publishers. Literary agents, and in some cases the writers themselves, independently canvassed British and North American presses in search of an international audience. ${ }^{28}$ Peter Carey offered to extend UQP's hardback rights to his short story collection, The fat man in history, internationally if the press could secure an appropriate publisher. His British literary agent, Elaine Markson, had sold his collection War crimes direct to Random House. When 1915 'took off' in Australia, McDonald encouraged the Press to obtain a North American publisher. He also asked the American poet Mark Strand to help find a publisher in the United States, and UQP was concerned that conflict with its own agent would confuse the message and disenfranchise them both. Strand ultimately played a role in interesting Brazillier, who had previously published the work of David Malouf and David Ireland, though Ireland was not a UQP author and Malouf negotiated his deal himself. ${ }^{29}$

David Carter describes the publication of Australian fiction in the United States in the 1980s as a 'boom', which he attributes to

the 'multi-nationalisation' of publishing globally, and the collapse of the Traditional Markets Agreement that had confined Australia to the British Publishing Sphere. Together these developments enabled a new trade in international rights where initial Australian publication was no longer the disadvantage it had been since the nineteenth century. ${ }^{30}$

The New York-based literary agent Elise Simon Goodman believed the interest in Australian books at the time was stimulated by the success of Australian film.

Brazillier proved an unreliable partner for UQP, however, as staff rotated on a frequent basis and the principal was seen as slow and difficult to work with. By March 1980, his press was reporting to UQP that the first print run of 5,000 had sold out. For the most part, the customers were libraries rather than book stores, and that frustrated attempts to find someone interested in the paperback rights. ${ }^{31}$ There was some hope that syndication of the mini-series in the United States would justify a North American paperback edition, but that failed to eventuate. ${ }^{32}$

Fontana printed 50,000 copies when it brought out the paperback version in Australia in 1980, with 40,000 of those going straight into bookshops. John Hooker tried to interest the English branch of the company in a paperback edition with no success. They followed the 1980 print run, with another tying in the television series when that was broadcast in 1982. Thomas Preis translated the novel into Swedish for Forum the same year. Faber and Faber, with whom UQP had established a working relationship through Robert McCrum, initially rejected the book, but eventually they brought out a paperback edition for the British market on the understanding that the BBC had purchased the mini-series. ${ }^{33}$

McDonald must have been quite happy with the success of his first novel. Within three years, he had British and American editions as well as a large print run paperback edition in Australia. The television series was allegedly sold to thirtyseven countries through the New York distributor Lionheart Productions. ${ }^{34} \mathrm{He}$ could have been in no doubt as to the significance of the role of film and television options in facilitating publishing opportunities and financial reward. The contract for the follow-up novel, Slipstream, limited UQP's overseas rights to two years, and McDonald used the fact that his contacts engaged the American publisher for 
1915 to bargain for 60 per cent rights to any offshore publishing agreement. He also insisted on the film and television rights; UQP countered with an offer of 90 per cent and the right to negotiate the sale himself.

Slipstream was published by UQP in the same year that the ABC broadcast 1915. The series boosted sales of the debut novel, and it may have helped the reception of the follow-up book, which was widely reviewed. The public seemed to have bought the reissue rather than the new novel, however, and in spite of being picked up by Faber and Faber in Britain and Little Brown in the United States, Slipstream appeared to make little impact. Fontana brought out a paperback edition the following year in the United Kingdom and McCrum told the author that the press was pleased with its reception and sales and looked forward to the next book. Little Brown sold 3,000 copies in North America - though mostly to libraries and neither it nor the Australian publisher was prepared to follow up the hardback with a soft-cover run. ${ }^{35}$ For a time, Michael Edgley showed interest in the film and television rights but in the end Slipstream failed to repeat the successes of the debut novel.

The high point for the second novel came in the United Kingdom rather than Australia. The Faber and Faber Autumn and Winter catalogue for 1982 features a picture of the writer wearing a large cowboy hat and a black shirt. It seems more typical of an American edition, for which it was also used as the inside back cover portrait. But McDonald found his place in Faber's international stable, cowboy hat and all, alongside the Guyanan experimentalist Wilson Harris, the cosmopolitan Anglo-Indian Lawrence Durrell (whose Constance or solitary practices was nominated for the Booker that year), the peer and crime novelist P. D. James; the American Ellen Gilchrist, whose Land of dreamy dreams - much like McDonald's 1915 - proved a big success for an aspiring university press at the University of Arkansas; and the promising American Laurel Goldman (Sounding the territory).

Roger McDonald's first two novels offer an interesting case study of an emerging Australian writer in the later part of the twentieth century. Tensions arise in an era of global exchange and post-colonial legacy from the different demands of culture as responsibility and culture as entertainment. Local subsidisation presents as a variety of investments in a readership that is imagined as both a market and a public. The internationalisation of that readership is characterised by considerations that challenge critical understanding and creative imagination. 'For whom does one write?' is an increasingly complex question for Australian writers interested in readers and a reputation.

\section{Endnotes}

1 Pascale Casanova, The world republic of letters, trans. M. B. Denovoise (Cambridge, MA: Harvard University Press, 2004), p. 85.

2 Susan Lever, 'Criticism and Fiction in Australia,' Overland 193 (Summer 2008), 65.

3 Dorothy Green, 'Puzzling lack of passion for our own literature', The National Times, 20 October 1979, 25. Clipping. Roger McDonald Papers NLA MS 5612 Box 15 Folder 57, Canberra.

4 He also edited The first paperback poets anthology in 1974 and published a volume of selected work with fellow poet Geoff Page in 1975. 
5 Ken Gelder and Paul Salzman, The new diversity: Australian fiction 1970-88 (Melbourne: McPhee Gribble, 1989), pp. 1-10.

6 Roger McDonald, 1915, Brisbane: University of Queensland Press, 1979.

7 Susan Lever, 'The challenge of the novel: Australian fiction since 1950', in The Cambridge history of Australian literature (Cambridge: Cambridge University Press, 2009), pp. 498516.

8 Roger McDonald, Slipstream, Brisbane: University of Queensland Press, 1982.

9 Barry Andrews, 'The empire strikes back: 1915 and the Australian sense of the past', in Mirko Jurak (ed.), Australian papers: Yugoslavia, Europe and Australia (Ljubljana, Slovenia: Faculty of Arts and Science, Edvard Kardelj University of Ljubljana, 1983), p. 180.

10 Roger McDonald Papers NLA MS 5612 Box 15 Folder 55, Canberra.

11 Pictures followed in the newspapers, along with a story of how the speaker of parliament was investigating damage to the front steps caused by the enthusiastic historical impersonators. The author later paid the bill.

12 David Rowbotham, 'It's a simple and deadly tale of war', 7 April 1979, Clipping in the Roger McDonald Papers NLA MS 5612, Series 5 1915, Folder 54.

13 Roger McDonald Papers NLA MS 5612. Box 17 Folder 70.

14 Barry Andrews, 'The empire strikes back'.

15 [1915]. Gallipoli Gazette 19(12) (Aug.-Sep. 1979). Clipping in Roger McDonald Papers NLA MS 5612 Box 15 Folder 54, Canberra.

16 McDonald, quoted Tony Stephens, 'Attack launches novel on Gallipoli', Sunday Telegraph, 8 April 1979, 134. Clipping in the Roger McDonald Papers NLA MS 5612, Series 5 1915, Folder 54.

17 Les Murray, 'Books of the year', 18. Emphasis added. Murray's view may be influenced by his experience of sharing accommodation at university with Bob Ellis. See Peter F. Alexander, Les Murray: A life in progress (Melbourne: Oxford University Press, 2000), pp. 6170.

18 McDonald, quoted in Susan Molloy, 'The harvest can wait: 1915's arrived', Sydney Morning Herald, 21 November 1981, 50. Clipping in the Roger McDonald Papers NLA MS 5612 Box 15 Folder 56, Canberra.

19 Tom O'Regan, 'Australian film in the 1970s: The ocker and the quality film', Australian Film in the Reading Room, accessed 20 September 2013, http://wwwmcc.murdoch.edu. au/ReadingRoom/film/1970s.html.

20 Graeme Turner, National fictions: Literature, film and the construction of Australian narrative (Sydney: Allen \& Unwin, 1984).

21 O'Regan, 'Australian film in the 1970s'.

22 Correspondence, George Braziller to Roger McDonald, 30 October 1981, Roger McDonald Papers NLA 5612 Series 2 Folder 15, Canberra.

23 It might be more accurate to think of it as an assembly of different kinds of minority audiences who become a majority public in number, but not in a shared or collective interpretation.

24 See Richard McBride, 'War is hell - especially for a novelist', Bulletin, 5 June 1979, 77; Peter Pierce, 'Minding everybody's business: The languages of recent Australian fiction', Meanjin 38(4) (1979), 501-9; Gavin O'Grady, 'Poet's approach makes a hard read', Nation Review, 14 June 1979, 623. Though for an alternate view, see Chris Wallace-Crabbe, 'Poets and other people', Times Literary Supplement, 11 January 1980, 30. 
25 1915, dir. Chris Thompson and Di Drew, Roadshow Entertainment, 1982.

26 Correspondence, Roger McDonald to Robert Gottleib, 22 January 1987, Roger McDonald Papers NLA MS 5612 Folder 7.

27 'Correspondence with agents', UQP Archives 198 Box 210, Fryer Library, University of Queensland, Brisbane. Also Deborah Jordan, 'American dreams and the University of Queensland Press', in Robert Dixon and Nicholas Birns (eds), Reading across the Pacific: Australia-United States intellectual histories (Sydney: Sydney University Press, 2010), pp. 323-38. My thanks to Deborah for generously providing me with a copy of her paper.

28 Jordan, 'American dreams'.

29 'Correspondence with agents', UQP Archives 198 Box 210, Fryer Library, University of Queensland, Brisbane.

30 David Carter, 'Trans-Pacific or trans-Atlantic traffic? Australian books and American publishers', in Dixon and Birns (eds), Reading across the Pacific, p. 356.

31 'Correspondence with agents'.

32 Roger McDonald to Robert Gottlieb, William Morris Agency, New York, correspondence, 21 January 1987. Folder 7 Series 2 Business papers 1964-92, Roger McDonald Papers MS 5612 NLA.

33 Robert McCrum to Roger McDonald, 7 July 1982, Roger McDonald Papers NLA MS 5612 Series 2 Business papers 1964-92, Canberra.

34 Folder 19 correspondence with Little Brown USA publishers, Roger McDonald Papers NLA MS 5612

35 That is until Picador released a paperback along with a reissue of McDonald's work a decade later, when Shearer's Motel was published. 